\title{
Multicentric Castleman's disease and Kaposi's sarcoma in a cyclosporin treated, HIV-I negative patient: case report JM Bollen ${ }^{1}$, AM Polstra ${ }^{2}$, AC van der Kuyl*2, JF Weel ${ }^{3}$, LA Noorduyn ${ }^{4}$, $\mathrm{MHJ}$ van Oers ${ }^{1}$ and $\mathrm{M}$ Cornelissen ${ }^{2}$
}

\begin{abstract}
Address: ${ }^{1}$ Dept. of Haematology, Academic Medical Centre, University of Amsterdam, PO Box 22660, 1100 DD Amsterdam, The Netherlands, ${ }^{2}$ Dept. of Human Retrovirology, Academic Medical Centre, University of Amsterdam, Meibergdreef 15, 1105 AZ Amsterdam, The Netherlands, ${ }^{3}$ Dept. of Medical Microbiology/Clinical Virology, Academic Medical Centre, University of Amsterdam, Meibergdreef 15, 1105 AZ Amsterdam, The Netherlands and ${ }^{4}$ Dept. of Pathology, Academic Medical Centre, University of Amsterdam, PO Box 22660, 1100 DD Amsterdam, The Netherlands

Email: JM Bollen - j.m.bollen@amc.uva.nl; AM Polstra - a.m.polstra@amc.uva.nl; AC van der Kuyl* - a.c.vanderkuyl@amc.uva.nl; JFWeel - j.f.weel@amc.uva.nl; LA Noorduyn - l.a.noorduyn@amc.uva.nl; MHJ van Oers - m.h.vanoers@amc.uva.nl; M Cornelissen - m.i.cornelissen@amc.uva.nl

* Corresponding author
\end{abstract}

Published: II December 2003

BMC Blood Disorders 2003, 3:3
Received: 01 September 2003

Accepted: II December 2003

This article is available from: http://www.biomedcentral.com/I47I-2326/3/3

(C) 2003 Bollen et al; licensee BioMed Central Ltd. This is an Open Access article: verbatim copying and redistribution of this article are permitted in all media for any purpose, provided this notice is preserved along with the article's original URL.

\begin{abstract}
Background: Multicentric Castleman's disease (MCD) is a rare disease, but is more frequent in AIDS patients. MCD has only been reported twice before in patients receiving immunosuppressive therapy after renal transplantation, and never in patients receiving immunosuppressive therapy without transplantation. About half of the cases of MCD are human herpesvirus 8 (HHV8) related, in contrast to Kaposi's sarcoma, a more common complication arising after immunosuppression, where the virus is found in virtually all cases.

Case presentation: We report a HIV-I negative, non-transplant patient who developed HHV8associated multicentric Castleman's disease and Kaposi's sarcoma after 17 years of immunosuppressive treatment with cyclosporin A for a minimal change nephropathy. Chemotherapy with liposomal doxorubicin resolved both symptoms of multicentric Castleman's disease and Kaposi's sarcoma in this patient. A concomitant decline in the HHV8 viral load in serum/plasma, as determined by a quantitative real-time PCR assay, was observed.
\end{abstract}

Conclusions: Multicentric Castleman's disease can be a complication of cyclosporin A treatment. Both multicentric Castleman's disease and Kaposi's sarcoma in this patient were responsive to liposomal doxorubicin, the treatment of choice for Kaposi's sarcoma at the moment, again suggesting a common mechanism linking both disorders, at least for HHV8-positive multicentric Castleman's disease and Kaposi's sarcoma.

HHV8 viral load measurements can be used to monitor effectiveness of therapy.

\section{Background}

Castleman's disease, also called angiofollicular or giant lymph node hyperplasia, is a clinically heterogeneous entity that can be either localized (unicentric), or multi- centric. The unicentric form, histopathologically described as the hyaline-vascular subtype, is more common, is not associated with HHV8-infection, and can mostly be treated effectively with radiotherapy or surgery 
as it presents as a solitary mass [1]. The multicentric form is less well understood: it is an atypical lymphoproliferative disorder of a plasma cell type, and is related to immune dysfunction. A mixture of both hyaline-vascular and plasma-cell variants can also be found [2]. Patients with MCD often develop malignancies like Kaposi's sarcoma and non-Hodgkin's lymphoma [2].

Human herpesvirus 8 (HHV8, or Kaposi's sarcoma-associated herpesvirus) infection is present in nearly $100 \%$ of multicentric Castleman's disease (MCD) cases associated with HIV-1 infection, and in about $50 \%$ of cases that are HIV-1 negative $[3,4]$. Recently, it has been proposed that HHV8-associated MCD is histologically distinct from HHV8-negative MCD [5,6]. Besides MCD and KS, HHV8 is also involved in a third disorder called primary effusion lymphoma (PEL). Interestingly, the HHV8-infected cells in MCD and PEL are of the B-cell lineage [7], while HHV8infected cells in KS are presumably endothelial cells with macrophage characteristics [8].

Clinically, HHV8-positive MCD is more aggressive, and has a poor prognosis with a median survival of less than 30 months $[2,4,9,10]$. MCD, whether or not HHV8-associated, is generally treated with combination chemotherapy (CHOP) and steroids [11].

\section{Case presentation}

In August 2002, a 38-year old homosexual, HIV-negative Dutch male was admitted to our hospital with high fever, night sweats, dyspnoea, coughing, weakness, hepatosplenomegaly, peripheral lymphadenopathy and oedema after returning from a holiday in Spain. Medical history revealed a minimal change nephropathy, for which he had been taking cyclosporin A (Neoral) for the past 17 years (5 mg/kg per day). Laboratory analysis revealed anaemia (haemoglobin $=4.6 \mathrm{mmol} / \mathrm{l}$ ), thrombocytopenia $\left(101 \times 10^{\%} / \mathrm{L}\right)$, normal WBC count and differential, renal failure (creatinine $=218 \mu \mathrm{mol} / \mathrm{l}$ ), hypoalbuminemia (24 g/l), and elevated CRP (133 mg/l). Diagnostic assays for HIV-1 were performed and repeatedly negative. No acute CMV or EBV infection was detected (by serology and PCR analysis). Chest X-ray showed interstitial infiltrates, however, bronchoalveolar lavage did not reveal an infectious agent. CT-scans revealed hepatosplenomegaly and enlarged abdominal lymph nodes. A bone marrow biopsy showed an active haematopoiesis in all cell lineages without any abnormalities.

Histological examination of an axillary lymph node biopsy (Fig. 1A) showed a multifocal proliferation of spindle cells. The diagnosis of Kaposi's sarcoma was confirmed by positive staining of these spindle cells with antibodies to factor VIII-related antigen (not shown) and
HHV8 (Fig. 1B). The remainder of the lymph node showed partly involuted germinal centres, surrounded by small lymphocytes. A number of these lymphocytes also stained positive for HHV8, as seen in multicentric Castleman's disease (Fig. 1C). The clinical syndrome and the histological findings were compatible with KS and MCD caused by a HHV8 infection in a long-term immunocompromised patient. HHV8 DNA load in serum or plasma was determined by real-time quantitative PCR [12], and was found to increase from $9.0 \times 10^{5}$ copies $/ \mathrm{ml}$ at the time of admission to $6.3 \times 10^{6}$ copies $/ \mathrm{ml}$ before treatment start (Fig. 2).

Despite discontinuation of cyclosporin A and supportive care his clinical condition deteriorated with fever, dyspnoea, oedema and exhaustion, together with the development of oral and facial KS lesions. Liposomal doxorubicin (Caelyx $20 \mathrm{mg} / \mathrm{m}^{2}$ ) was initiated at three-week intervals, ten days after discontinuation of Neoral. Although Caelyx is nowadays the drug of choice to treat KS [13], it has not been reported as a treatment for $\mathrm{MCD}$, however, it has been shown to lower the HHV8 load [14], suggesting it may also have an effect on other HHV8-related diseases. HHV8 viral load has earlier been associated with clinical outcome in both KS and MCD, whereby a decrease in viral load measured in blood was linked to a favourable outcome [15-18], and an increase in HHV8 viral load with exacerbations in clinical symptoms [19-21].

Within two weeks after treatment start he clinically improved with disappearance of hepatomegaly, lymphadenopathy, and pulmonary infiltrates, and all laboratory parameters became normal. Simultaneously, the HHV8 load dropped to $7.4 \times 10^{4} \mathrm{copies} / \mathrm{ml}$, but started to rise again after two weeks to $1.7 \times 10^{5}$ copies $/ \mathrm{ml}$, with recurrence of his clinical symptoms. After the second course of Caelyx, the HHV8 load decreased to $1.1 \times 10^{3}$ copies $/ \mathrm{ml}$. The treatment response was again transient and three weeks later his HHV8 load had risen to $2.4 \times 10^{4}$ copies/ $\mathrm{ml}$. After the third Caelyx treatment the viral load was permanently reduced to around the detection limit of the assay $\left(1.66 \times 10^{2}\right.$ copies $\left./ \mathrm{ml}\right)$. Another three courses of Caelyx were given. Fourteen months later he is still disease free without fever, lymphadenopathy or KS lesions. Immunosuppressive therapy with cyclosporin A was discontinued, which is expected to contribute to the ongoing remission.

KS specifically occurs under cyclosporin A therapy in about $0.87 \%$ of renal transplant patients [22]. MCD however, is rarely seen under immunosuppressive treatment after transplantation $[23,24]$, and has never been reported before in non-transplant patients treated with cyclosporin A [25]. 

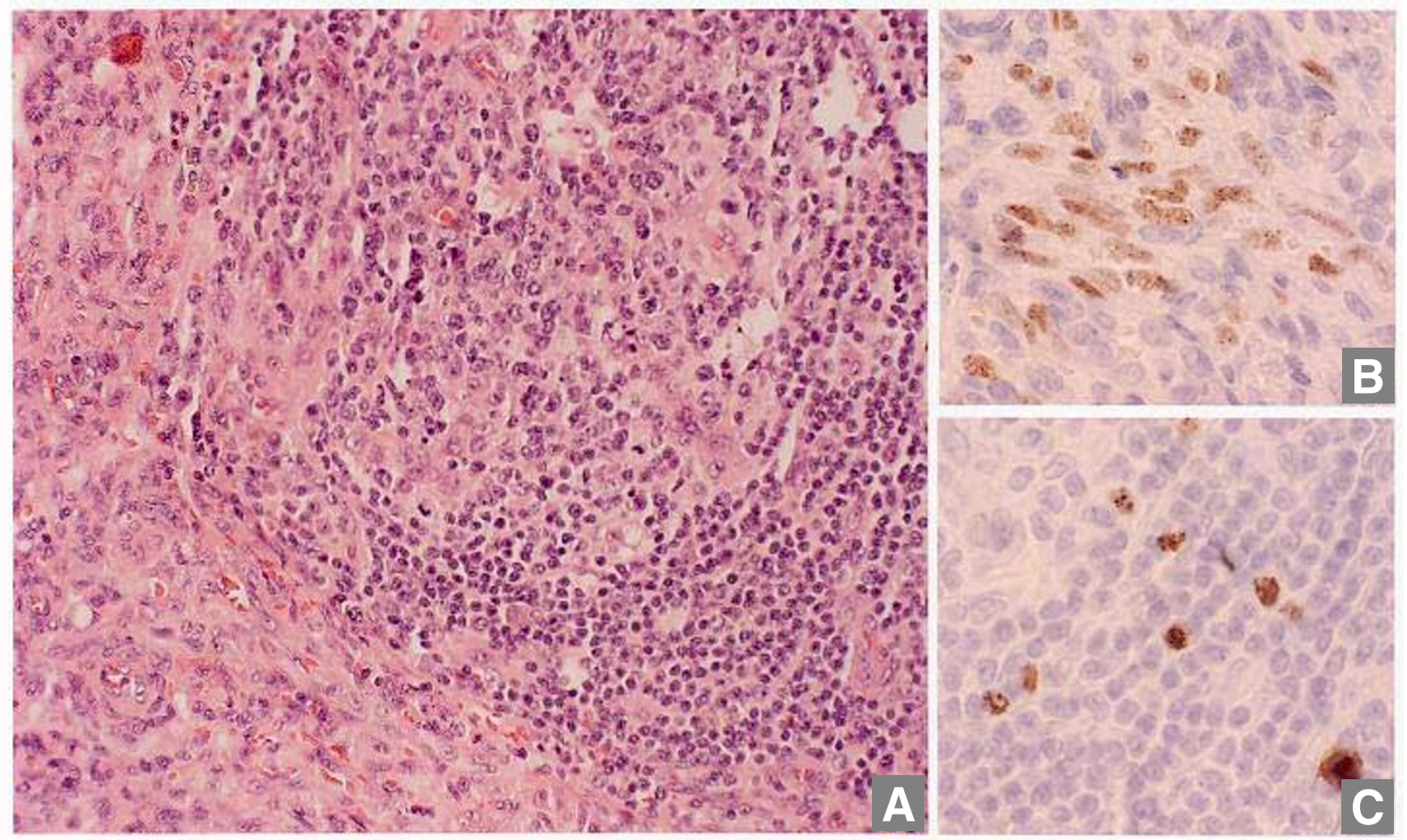

\section{Figure I}

Microscopic morphology of representative lymph node sections and immunohistochemical detection of HHV8 infection. A: Histology of the axillary lymph node showing proliferation of spindle cells (lower left) and partly involuted germinal center, surrounded by small lymphocytes (upper right). B: HHV8 positive spindle cells. C: HHV8 positive lymphocytes in the follicular mantle zone.

Retrospective analysis of the stored serum samples with the Diavir HHV8 peptide mix ELISA (Biotrin International, Dublin, Ireland) showed that this patient was already IgG antibody-positive with very high titres at presentation (result not shown), making an acute HHV8 infection unlikely. As expected, all subsequent serum samples were also HHV8 antibody-positive (results not shown). So, the relatively late development of MCD in this homosexual patient (arising only after 17 years of cyclosporin treatment) is most probable due to a reactivation of an existing HHV8 infection. However, the HHV8 infection might be younger than the start of cyclosporin treatment 17 years ago, and as no earlier serum samples were available, it is difficult to estimate the time period elapsed between HHV8 infection and development of
MCD. In The Netherlands, HHV8 infections are more common among men having sex with men than in the general population or any other risk group [26], making homosexuality the main risk factor for HHV8 acquisition, with iatrogenic immunosuppression being the risk factor for subsequent MCD development in this patient.

In general MCD has a poor prognosis with a rapidly fatal clinical course $[4,9,10]$, therefore it is remarkable that in this case the patient responded well to Caelyx therapy, showing a concomitant decline of the HHV8 load in blood. Interestingly, a case of EBV-negative post-transplantation lymphoproliferative disorder (PTLD), attributed to a transplantation-associated HHV8-infection in a 17 year-old boy, responded only to a combination of 


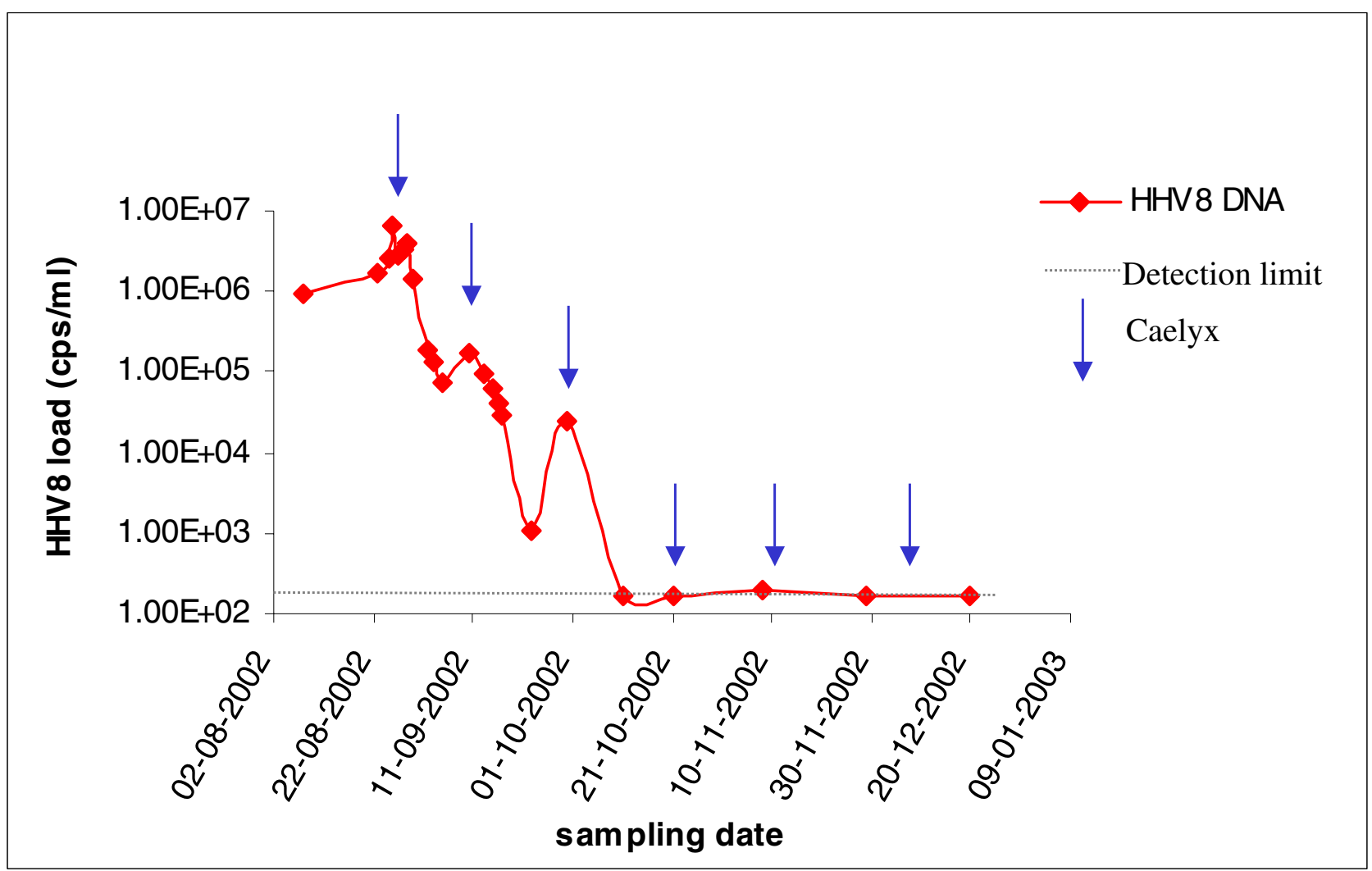

\section{Figure 2}

HHV8 DNA load of consecutive serum/plasma samples from the case measured with real-time PCR. Arrows indicate the chemotherapy courses. All samples were HHV8 IgG antibody-positive.

liposomal daunorubicin and alpha-interferon [27]. EBVpositive PTLD's, but not EBV-negative cases, have been found to respond to withdrawal of immunosuppression alone [27]. Possibly, HHV8-associated lymphoproliferative disorders share common features, and require similar treatment.

\section{Conclusions}

MCD can arise as a complication of cyclosporin treatment. HHV8 viral load measurements are indicative of effectiveness of therapy in HHV8-associated MCD.

$\mathrm{MCD}$, as well as KS, in this patient was responsive to liposomal doxorubicin, the treatment of choice for KS at the moment, again suggesting a common mechanism linking both disorders.

\section{List of abbreviations used}

MCD = multicentric Castleman's disease, $\mathrm{KS}=$ Kaposi's sarcoma, $\mathrm{PEL}=$ primary effusion lymphoma, HHV8 = Human herpesvirus 8, HIV-1 = human immunodeficiency virus type $1, \mathrm{WBC}=$ white blood cell count, $\mathrm{CRP}=\mathrm{C}$-reactive protein, $\mathrm{CMV}=$ Cytomegalovirus, $\mathrm{EBV}=$ Epstein-Barr virus, $\mathrm{PCR}=$ polymerase chain reaction, $\mathrm{PTLD}=$ post transplantation lymphoproliferative disorder.

\section{Competing interests}

None declared.

\section{Authors' contributions}

$\mathrm{JMB}$ and $\mathrm{MHJVO}$ treated the patient and organised clinical and laboratory investigations, AMP and MC performed the real-time HHV8 PCR assays, JFW did the other bacterial and viral diagnostic assays, LAN did histopathological 
analysis and immunohistochemistry, and ACvdK drafted the manuscript. All authors read and approved the final manuscript.

\section{Acknowledgements}

We thank Remco van den Burg for performing the HHV8 ELISA. Written consent was obtained from the patient for publication of the patient's details.

\section{References}

I. Frizzera G: Castleman's disease and related disorders. Semin Diagn Pathol 1988, 5:346-364.

2. Larroche C, Cacoub P, Soulier J, Oksenhendler E, Clauvel JP, Piette JC, Raphael M: Castleman's disease and lymphoma: report of eight cases in HIV-negative patients and literature review. Am J Hematol 2002, 69:1 19-126.

3. Soulier J, Grollet L, Oksenhendler E, Cacoub P, Cazals-Hatem D, Babinet P, D'Agay M-F, Clauvel J-P, Raphael M, Degos L, Sigaux F: Kaposi's sarcoma-associated herpesvirus-like DNA sequences in multicentric Castleman's disease. Blood 1995, 86: $1276-1280$.

4. Dupin N, Fisher C, Kellam P, Ariad S, Tulliez M, Franck N, van Marck E, Salmon D, Gorin I, Escande JP, Weiss RA, Alitalo K, Boshoff C: Distribution of human herpesvirus-8 latently infected cells in Kaposi's sarcoma, multicentric Castleman's disease, and primary effusion lymphoma. Proc Natl Acad Sci U S A 1999, 96:4546-455I.

5. Dupin N, Diss TL, Kellam P, Tulliez M, Du MQ, Sicard D, Weiss RA, Isaacson PG, Boshoff C: HHV-8 is associated with a plasmablastic variant of Castleman disease that is linked to HHV-8-positive plasmablastic lymphoma. Blood 2000, 95: | 406-| 4 I 2.

6. Amin HM, Medeiros LJ, Manning JT, Jones D: Dissolution of the lymphoid follicle is a feature of the HHV8+ variant of plasma cell Castleman's disease. Am J Surg Pathol 2003, 27:9I-I00.

7. Cesarman E, Chang Y, Moore PS, Said JW, Knowles DM: Kaposi's sarcoma-associated herpesvirus-like DNA sequences in AIDS- related body-cavity-based lymphomas. $N$ Engl J Med 1995, 332: I|86-| |91.

8. Uccini S, Ruco LP, Monardo F, Stoppacciaro A, Dejana E, La Parola IL, Cerimele D, Baroni CD: Co-expression of endothelial cell and macrophage antigens in Kaposi's sarcoma cells. J Pathol 1994, | 73:23-3|

9. Parravinci C, Corbellino M, Paulli M, Magrini U, Lazzarino M, Moore PS, Chang Y: Expression of a virus-derived cytokine, KSHV vIL-6, in HIV-seronegative Castleman's disease. Am J Pathol 1997, I51:1517-1522.

10. Chadburn A, Cesarman E, Nador RG, Liu YF, Knowles DM: Kaposi's sarcoma-associated herpesvirus sequences in benign lymphoid proliferations not associated with human immunodeficiency virus. Cancer 1997, 80:788-797.

II. Chronowski GM, Ha CS, Wilder RB, Cabanillas F, Manning J, Cox JD: Treatment of unicentric and multicentric Castleman disease and the role of radiotherapy. Cancer 2001, 92:670-676.

12. Polstra AM, van den Burg R, Goudsmit J, Cornelissen M: Human Herpesvirus 8 Load in Matched Serum and Plasma Samples of Patients with AIDS-Associated Kaposi's Sarcoma. J Clin Microbiol 2003, 41:5488-549I.

13. Northfelt DW, Dezube BJ, Thommes JA, Miller BJ, Fischl MA, Friedman-Kien A, Kaplan LD, Du Mond C., Mamelok RD, Henry DH: Pegylated-liposomal doxorubicin versus doxorubicin, bleomycin, and vincristine in the treatment of AIDS-related Kaposi's sarcoma: results of a randomized phase III clinical trial. J Clin Oncol 1998, I 6:2445-245I.

14. Nunez M, Machuca A, Soriano V, Podzamczer D, Gonzalez-Lahoz J: Clearance of human herpesvirus type 8 viraemia in HIV-Ipositive patients with Kaposi's sarcoma treated with liposomal doxorubicin. Caelyx/KS Spanish Study Group. AIDS 2000, 14:913-919.

15. Prins JM, Sol CJA, Renwick N, Goudsmit J, Veenstra J, Reiss P: Favourable effect of chemotherapy on clinical symptoms and human herpesvirus-8 DNA load in a patient with Kaposi's sarcoma presenting with fever and anemia. Eur Clin Microbiol Infect Dis 1999, I 8:499-502.
16. Wit FWN, Sol CJA, Renwick N, Roos MTL, Pals ST, Van, Leeuwen R, Goudsmit J, Reiss P: Regression of AIDS-related Kaposi's sarcoma associated with clearance of human herpesvirus-8 from peripheral blood mononuclear cells following initiation of antiretroviral therapy [2]. AIDS 1998, 12:218-219.

17. Boivin G, Cote S, Cloutier N, Abed Y, Maguigad M, Routy JP: Quantification of human herpesvirus 8 by real-time PCR in blood fractions of AIDS patients with Kaposi's sarcoma and multicentric Castleman's disease. J Med Virol 2002, 68:399-403.

18. Pellet C, Chevret S, Blum L, Gauville C, Hurault M, Blanchard G, Agbalika F, Lascoux C, Ponscarme D, Morel P, Calvo F, Lebbe C: Virologic and immunologic parameters that predict clinical response of AIDS-associated Kaposi's sarcoma to highly active antiretroviral therapy. J Invest Dermatol 200I, I | 7:858-863.

19. Grandadam M, Dupin N, Calvez V, Gorin I, Blum L, Kernbaum S, Sicard D, Buisson Y, Agut H, Escande JP, Huraux JM: Exacerbations of clinical symptoms in human immunodeficiency virus type I-infected patients with multicentric Castleman's disease are associated with a high increase in Kaposi's sarcoma herpesvirus DNA load in peripheral blood mononuclear cells. J Infect Dis 1997, I75:I198-1201.

20. De Jong RB, Kluin PM, Rosati S, Van Haelst PL, Sprenger HG, Van Spronsen DJ: Sustained high levels of serum HHV-8 DNA years before multicentric Castleman's disease despite full suppression of HIV with highly active antiretroviral therapy. AIDS 2003, I 7:1407-I408.

21. Pellet C, Chevret S, Frances C, Euvrard S, Hurault M, Legendre C, Dalac S, Farge D, Antoine C, Hiesse C, Peraldi MN, Lang P, Samuel D, Calmus Y, Agbalika F, Morel P, Calvo F, Lebbe C: Prognostic value of quantitative Kaposi sarcoma--associated herpesvirus load in posttransplantation Kaposi sarcoma. J Infect Dis 2002, I 86: II0-II3.

22. Lessan-Pezeshki M, Einollahi B, Khatami MR, Mahdavi M: Kidney transplantation and Kaposi's sarcoma: review of 2050 recipients. Transplant Proc 2001, 33:2818.

23. Mandel C, Silberstein M, Hennessy O: Case report: fatal pulmonary Kaposi's sarcoma and Castleman's disease in a renal transplant recipient. Br J Radiol 1993, 66:264-265.

24. Cagirgan S, Cirit M, Ok E, Sencan M, Hekimgil M, Unsal A, Saydam G, Tokat $Y$ : Castleman's disease in a renal allograft recipient. Nephron 1997, 76:352-353.

25. Vial T, Descotes J: Immunosuppressive drugs and cancer. Toxicology 2003, I 85:229-240.

26. Renwick N, Halaby T, Weverling G], Dukers NHTM, Simpson, GR, Coutinho RA, Lange LMA, Schulz TF, Goudsmit J: Seroconversion for human herpesvirus 8 during HIV infection is highly predictive of Kaposi's sarcoma. AIDS 1998, I 2:248I-2488.

27. Kapelushnik J, Ariad S, Benharroch D, Landau D, Moser A, Delsol G, Brousset P: Post renal transplantation human herpesvirus 8associated lymphoproliferative disorder and Kaposi's sarcoma. Br J Haematol 200 I, I I 3:425-428.

\section{Pre-publication history}

The pre-publication history for this paper can be accessed here:

\section{http://www.biomedcentral.com/1471-2326/3/3/prepub}

